\title{
FLUID BED DIRECT DENITRATION PROCESS \\ FOR PLUTONIUM NITRATE TO OXIDE CONVERSION
}

\author{
Kenneth R. Souply
}

David H. Neal

Chemistry Research and Development

PROCESS CHEMISTRY AND ENGINEERING GROUP

Work performed under 189 No. F-AL-10-001

for the

Savannah River Operations Office

U.S. Energy Research and Development Administration

\section{Rockwell International}

Atomics International Division

Rocky Flats Plant

P.O. Box 464

Golden, Colorado 80401 


\section{DISCLAIMER}

This report was prepared as an account of work sponsored by an agency of the United States Government. Neither the United States Government nor any agency Thereof, nor any of their employees, makes any warranty, express or implied, or assumes any legal liability or responsibility for the accuracy, completeness, or usefulness of any information, apparatus, product, or process disclosed, or represents that its use would not infringe privately owned rights. Reference herein to any specific commercial product, process, or service by trade name, trademark, manufacturer, or otherwise does not necessarily constitute or imply its endorsement, recommendation, or favoring by the United States Government or any agency thereof. The views and opinions of authors expressed herein do not necessarily state or reflect those of the United States Government or any agency thereof. 


\section{DISCLAIMER}

Portions of this document may be illegible in electronic image products. Images are produced from the best available original document. 


\section{LEGAL NOTICE}

This report was prepared as an account of work sponsored by the United States Government. Neither the United States nor the Energy Research and Development $\Lambda$ dministration, nor any of their employees, nor any of their contractors, subcontractors, or their employees, makes any warranty, expressed or implied, or assumes any legal liability or responsibility for the accuracy, completeness or usefulness of any information, apparatus, product or process disclosed, or represents that its use would not infringe privately owned rights.

Printed in the United States of America

Available from the

National Technical Information Service

U.S. Department of Commerce

Springfield, Virginia 22161

Price: Printed Copy $\$ 4.50$ Microfiche $\$ 3.00$

Price Is Subject to Change Without Notice 


\section{FLUID BED DIRECT DENITRATION PROCESS}

\section{FOR PLUTONIUM NITRATE TO OXIDE CONVERSION}

Kenneth R. Souply

David H. Neal

Chemistry Research and Devclopment

PROCESS CHEMISTRY AND ENGINEERING GROUP

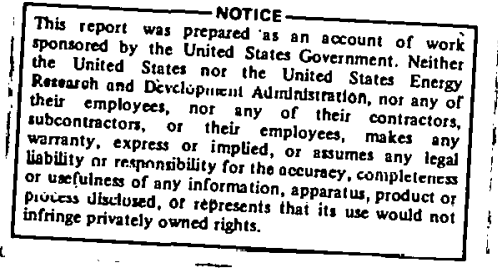

SUBJECT DESCRIPTORS

Plutonium Processing

Plutóniun Nitrates

Plutonium Oxides

ROCKWELL INTERNATIONAL

ATOMICS INTERNATIONAL DIVISION

ROCKY FLATS PLANT

P.O. BOX 464

GOLDEN, COLORADO 80401

Prepared under Contract EY-76-C-04-3533

for the

Albuquerque Operations Office

U.S. Energy Research and Development Administration 


\section{THIS PAGE \\ WAS INTENTIONALLY \\ LEFT BLANK}




\section{CONTENT S}

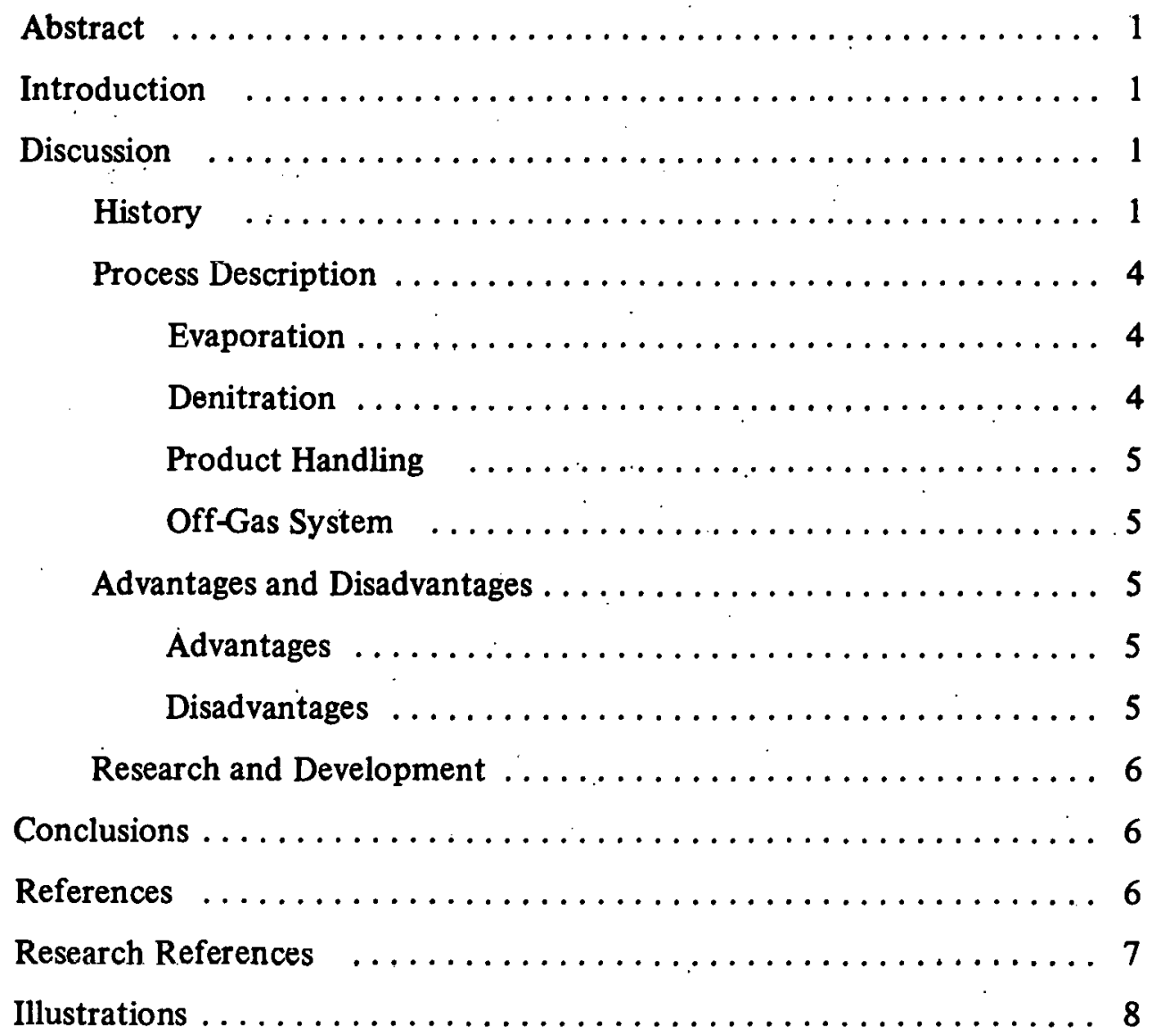

(Figures 1 through 3) 


\section{ACK N O W LE D GM E N TS}

Appreciation is expressed, for the preparation of this report, to the following members of the PNO Project Team: Rosamond M. Greinetz, George D. Lehemkuhl, and Walter E. Sperry. 


\title{
FLUID BED DIRECT DENITRATION PROCESS
}

\section{FOR PLUTONIUM NITRATE TO OXIDE CONVERSION}

\author{
Kenneth R. Souply and David H. Neal
}

\begin{abstract}
The fluid bed direct-denitration process appears feasible for reprocessing Light Water Reactor fuel. Considerable experience with the fluid bed process exists in the denitration of uranyl nitrate and it shows promise for use in the denitration of plutonium nitrate. The process will require some development work before it can be used in a production-size facility. This report describes a fluid bed direct-denitration process for converting plutonium nitrate to plutonium oxide, and the information should be used when making comparisons of alternative processes or as a basis for further detailed studies.
\end{abstract}

\section{INTRODUCTION}

This report contains information which may be used as a basis when comparing fluid bed directdenitration to other plutonium nitrate-to-oxide (PNO) conversion processes. The information should also be used when initiating development of a prototype or plant-scale facility.

Reprocessing of Light Water Reactor (LWR) fuel elements includes separation of plutonium $(\mathrm{Pu})$ from the uranium (U) and from unwanted fission products. The PUREX solvent-extraction process separates $\mathrm{Pu}$ as plutonium nitrate $\left[\mathrm{Pu}\left(\mathrm{NO}_{3}\right)_{\mathbf{X}}\right]$ in an aqueous nitric acid $\left(\mathrm{HNO}_{3}\right)$ stream. Shipping regulations ${ }^{1}$ require that the $\mathrm{Pu}$ be in a solid form. Since plutonium oxide $\left(\mathrm{PuO}_{2}\right)$ powder is used in the fabrication of mixed uranium-plutonium oxide reactor fuels, $\mathrm{PuO}_{2}$ is a logical choice of form of the $\mathrm{Pu}$ product from a fuel reprocessing plant.

Therefore, it is necessary to choose a process for converting the plutonium nitrate to plutonium oxide.

Each time an industrial or government organization considers building a plutonium nitrate-to-oxide conversion facility, various candidate processes are compared before making a final process selection. The final selection of a process depends on the criteria developed by that organization, and on the knowledge that organization has about the processes. Such a comparison is being made as part of the Rocky Flats PNO Conversion Project. A report will be issued presenting an evaluation of the processes, and discussing them as they relate to the evaluation criteria.

The following processes are being considered: Plutonium(IV) oxalate-precipitation and calcination, plutonium(III) oxalate-precipitation and calcination, plutonium peroxide-precipitation and calcination, fluid bed direct-denitration, screw-calciner mechanical direct-denitration, batch directdenitration, and Sol Gel.

The intent of this report, and others in this series, is to provide information to be used in comparing the above processes. The report includes the relative advantages and disadvantages; the history, and a detailed description of the process, complete with a block flow diagram, Figure 1, and equipment flow sheet, Figure 3.

\section{DISCUSSION}

\section{History}

Development of a fluidized bed for application to the denitration of uranyl nitrate $\left[\mathrm{UO}_{2}\left(\mathrm{NO}_{3}\right)_{2}\right]$ and aluminum nitrate $\left[\mathrm{Al}\left(\mathrm{NO}_{3}\right)_{3}\right]$ solutions was undertaken in 1953 by the Argonne National Laboratory. ${ }^{2}$ This work was done in an attempt to replace the batch technique then in use.

Two sizes of equipment were used in the development work. The first was a 3-inch diameter benchscale unit used for exploratory runs to determine 
the feasibility of the process and to establish the approximate operating conditions. The second was a 6-inch reactor made from Type 304 stainless steel and consisted of the following three sections: a gas dispersion chamber, a reaction chamber, and a disengaging section. The overall height of the unit was 64 inches. The reaction chamber was heated by thirty 1000-watt tubular heaters set into grooves in the chamber wall.

Thirty runs, each lasting about 8 hours, were made. These runs produced about 5,000 pounds of uranium trioxide $\left(\mathrm{UO}_{3}\right)$. Particle growth was a problem but was controlled by careful manipulation of temperature and feed concentration.

The spray nozzle was a type in which atomization occurred externally. This type nozzle produced less caking. Mounting the nozzle horizontally, with the tip flush with the inner wall, helped to prevent caking around the nozzle. No corrosion, which could cause impurities in the product, was experienced.

In the early 1950's, the Australian Atomic Energy Commission established a pilot-scale plant for the denitration of $\mathrm{UO}_{2}\left(\mathrm{NO}_{3}\right)_{2} \cdot{ }^{3}$ The pilot unit was 9 inches in diameter, with a 3-foot operating bed depth. Power input to the bed was approximately 20 kilowatts (kW).

Considerable trouble was experienced by partially decomposed nitrate collecting on the nozzle. Experience showed that the nozzle should be 2 to 3 inches from the vessel wall and at least a foot beneath the surface of the solids. Eventually, 1000 operating hours were achieved without cleaning the nozzle.

On the basis of Argonne National Laboratory's work, Mallinckrodt Chemical Works placed a similar fluid-bed denitrator in operation in September $1957 . .^{4}$ Development of the process was initiated with the installation of a pilot-plant denitrator at the Destrehan Street Plant in Weldon Spring, Missouri. After 21 experimental runs, a new and somewhat modified pilot denitrator was installed at the newly-constructed Weldon Spring Plant.
The major physical difference between the two reactors was the greater height-to-diameter ratio of the Weldon Spring unit. Major operating differences at Weldon Spring were the use of fluidizing velocities considerably in excess of those employed at Destrehan Street, and of higher concentrations of $\mathrm{UO}_{2}\left(\mathrm{NO}_{3}\right)_{2}$. A total of 142 experimental runs were made at the Weldon Spring Plant.

The early development work at Mallinckrodt led to two obvious conclusions:

1. Sustained operation of continuous fluid-bed denitrator at rates equal to or greater than 350 pouids per livur per square foot of reactor cross section is practical with uranyl nitrate concentrations of up to 11.8 pounds of $U$ per gallon.

2. Although a strict statistical experiment to completely determine the effects and interactions of all known variables was never carried out, it is obvious that the physical characteristics of the product can be varied within limits by minor variations in the operating conditions. Experimental ıesults indicated that an increase in the bod temperature, feed concentration, sulfate content, or production rate would generally tend to increase the mean particle size. Also, changes in the fluidizing velocity generally lead to changos in the particle size distribution.

A plant-scale fluid-bed denitration system was installed at the Weldon Spring refinery in May 1964..$^{5}$ Subsequent development was aimed at trying to obtain a more reactive oxide for subsequent hydrofluorination. Although this could not be done in the reactor, it was found that soaking the $\mathrm{UO}_{3}$ in uranyl nitrate hexahydrate $\left[\mathrm{UO}_{2}\left(\mathrm{NO}_{3}\right)_{2} \cdot 6 \mathrm{H}_{2} \mathrm{O}\right]$ would provide the necessary reactivity.

Three major problems were noted in the operation of the plant-scale reactor:

1. Severe salt leakage developed at the middle and bottom denitrator flange sets. Thermal shock on startup apparently distorted the flanges, and the problem was never completely resolved. 
2. Plugging of the nozzles from improper flushing of the nozzles and recycle lines or overconcentration of the uranyl nitrate hexahydrate could be decreased by reducing the number of startups and shutdowns. Cake formation on the nozzle tips appeared to occur gradually from an accumulation of $\mathrm{UO}_{3}$ from spray backflow. Reduction of nozzle protrusion into the denitrator to a minimum may have reduced the amount of cake formation and make nozzle maintenance easier, but complete elimination of the caking was doubtful.

3. A problem of filter tubes backing out of their threads and falling into the bed was overcome by welding a connecting rod to each filter tube.

The overall on-stream-factor for the plant-scale fluid bed reactor was about 70 percent. Approximately 9 percent downtime was associated with startup and shutdown, 15 percent with periodic acid cleaning, and 6 percent with general maintenance. Maintenance downtime would have been greater if maintenance work could not have been done during the other downtime periods.

For reasons not completely disclosed, the Mallinckrodt plant was closed on April 28, 1966.

The Idaho Chemical Processing Plant (ICPP) installed a fluid bed reactor in 1970 to convert $\mathrm{UO}_{2}\left(\mathrm{NO}_{3}\right)_{2}$ solution to $\mathrm{UO}_{3} .{ }^{6}$ The conversion of the plant inventory of $\mathrm{UO}_{2}\left(\mathrm{NO}_{3}\right)_{2}$ solution was successfully completed in January 1971. This plant-scale compaign was accomplished after a lengthy cold startup of the process, during which time many mechanical problems were identified and resolved.

Approximately 800 kilograms $(\mathrm{kg})$ of highly enriched uranium in a solution averaging 365 grams of $U$ per litre of solution were processed in fourteen days of plant opcration.

One major ditference between ICPP's pivcess and - those used at Argonne and Mallinckrodt was that the feed concentration at ICPP was 350 grams of $U$ per litre of solution in a $0.1 M \mathrm{HNO}_{3}$ solution, whereas, the other processes used molten $\mathrm{UO}_{2}\left(\mathrm{NO}_{3}\right)_{2}$ at a concentration of about 650 grams of $\mathrm{U}$ per litre of solution.?
Initial testing of the ICPP plant unit revealed the following problems:

1. Poor feed control

2. Excessive generation of fines

3. Bed caking

4. Heater problems

5. Nozzle plugging

6. Plugging of pressure probes

7. Restrictions in the product overflow line

8. Restrictions in the bed removal line

The following conclusions were reached from the production experience at ICPP:

1. Chunks of $\mathrm{UO}_{3}$ will probably be formed during every run. Some mechanical means are needed to keep the overflow line open.

2. Plugging of the feed nozzles and pressure probes can be a serious problem in a $\mathrm{UO}_{3}$ bed having a filter blowback system. Elimination of all air traps in the feed line will minimize nozzle plugging. Use of check valves on pressure probes that extend downward into the bed for some distance will minimize plugging.

3. General conclusions drawn about particle growth:

a. High temperature promotes growth. Low temperature may allow an equilibrium to be established.

b. Thermal shocking can be effectively used to reduce particle size.

c. High sulfate promotes growth. Low sulfate may allow an equilibrium to be established.

d. Jet grinding can be used to reduce particle size.

4. Proper assembly of the nozzle is very important. The nozzles should be visually tested before installation.

Most of the operation of the fluid bed at ICPP was done in the temperature range of 300 to $400{ }^{\circ} \mathrm{C}$. When the equipment required cleaning, as in the case of severe plugging, it was flushed with $3 M \mathrm{HNO}_{3}$ followed by a water rinse, repeated several times. 
Work cited in a paper by P. G. Alfredson in 1972, shows that the Australian Atomic Energy Commission was using a single fluidized bed to both denitrate and reduce ammonium diuranate (ADU) to obtain $\mathrm{UO}_{2}{ }^{8}$ This work first involved using the fluid bed as a batch operation in which a single charge of material was both calcined and reduced in the fluid bed reactor. Then a batch-continuous operation was tried in which ADU was fed continuously to the top, the bed allowed to build up to a maximum level, and the feed subsequently turned off to allow the contents to calcine and reduce.

Finally, a continuous operation was tried in which the feed was left on with the calcining and reduction occurring simultaneously. Apparently, the processes worked well, as approximately $1500 \mathrm{~kg}$ of yellow cake was processed to $\mathrm{UO}_{2}$ powder. It was reported that all of the $\mathrm{UO}_{2}$ powder produced in the fluid bed was more readily pelletized and has shown a lower incidence of cracking and pellet defects than powder produced by batch-tray calcinationreduction.

The first fluid-bed denitration of solution containing plutonium was done at Argonne National Laboratory, Chicago, Illinois. The early experimental work was with a uranyl nitrate-plutonium nitrate solution. ${ }^{9}$

The first denitration runs with $\mathrm{U} / \mathrm{Pu}$ feed were aimed at continuing the displacement of the original $\mathrm{UO}_{3}$ bed with $\mathrm{UO}_{3}-\mathrm{PuO}_{2}$ to achieve steady state with respect to product composition. The product at that time contained about 2 percent plutonium. This was in the range of interest for plutonium recycle fuel. The pilot plant possessed a feed makeup system of limited capacity and the runs were limited to approximately 10 to 15 hours each. Several runs were necessary to provide the number of bed displacements needed to achieve a steadystate composition.

The particle size could be controlled by the use of a jet grinder, although in the later runs, the jet grinder was not needed.

All of the U/Pu studies were conducted in a 4-inch diameter pilot plant reactor. ${ }^{10}$ The process appeared to be applicable over the entire concentration range of $\mathrm{U} / \mathrm{Pu}$ materials, as well as for $\mathrm{Pu}$ alone.
Only two runs were made using plutonium nitrate as the feed solution. These runs were relatively short (46 min, $3.25 \mathrm{hr}$ ) and produced $\mathrm{PuO}_{2}$ at a rate of 750 grams per hour. No difficulty was experienced and $\mathrm{Pu}$ seemed more easily processed than $\mathrm{U}$.

\section{Process Description}

The fluid bed direct-denitration process converts $\mathrm{Pu}\left(\mathrm{NO}_{3}\right)_{\mathrm{X}}$ solutions to a $\mathrm{PuO}_{2}$ solid suitable for blending with uranium oxide $\left(\mathrm{UO}_{2}\right)$, and fabrication into fuel pellets for LWR fuel.

The main process stream and the waste streams are shown in Figure 1, appearing at the end of the text. The main stream starts with the storage of the feed solution. It is then evaporated, with the bottoms stream from the evaporator being sent to storage tanks. The more concentrated solution is then fed to the calciner where it emerges as the $\mathrm{PuO}_{2}$ solid. This is then screened and packaged as the finished product.

A detailed description of the process is given below. A description of the equipment and a material balance are shown in Figure 3.

\section{Evaporation}

The denitration-unit feed from the separations unit is assumed to be 250 grams of Pu per litre $(\ell)$ of solution with a $\mathrm{HNO}_{3}$ concentration of $3 M$. This feed is concentrated to 417 grams of $P u$ per $\ell$ of solution for feed to the denitration reactor. The evaporator overhead, at $0.5 \mathrm{M} \mathrm{HNO}_{3}$, is sent to distillate storage. The distillate is sampled for $\mathrm{Pu}$ and, if acceptable, is then sent to the Waste Treatment unit. If not acceptable, it is sent to the feed evaporator.

\section{Denitration}

The concentrated feed from evaporation is fed to three denitration reactors in parallel. The reactors contain beds of $\mathrm{PuO}_{2}$ which are fluidized with air. The plutonium nitrate solution is atomized with air and sprayed into the bed where evaporation of 
the water and $\mathrm{HNO}_{3}$ takes place. The plutonium nitrate calcines on the $\mathrm{PuO}_{2}$ particles to $\mathrm{PuO}_{2}$. As the bed increases in size, it overflows to a product accumulator. The air, vapors, and off-gas pass through a set of sintered metal filters to a condenser. The overall calcination reaction is believed to be:

$$
\mathrm{Pu}\left(\mathrm{NO}_{3}\right)_{4} \stackrel{\Delta}{\rightarrow} \mathrm{PuO}_{2}+3.4 \mathrm{NO}_{2}+0.6 \mathrm{NO}+1.3 \mathrm{O}_{2}
$$

\section{Product Handling}

The $\mathrm{PuO}_{2}$ product from the product accumulator is ground, screened, and packaged for shipment or storage.

\section{Off-Gas System}

The reactor off-gas stream goes to a condenser where water and $\mathrm{HNO}_{3}$ are condensed. The condensate then goes to storage. The condenser off-gas is sent to a venturi scrubber where it is scrubbed with water. Very fine $\mathrm{PuO}_{2}$ which may have remained in the condenser off-gas and residual $\mathrm{HNO}_{3}$ are removed from the off-gas stream. Some oxides of nitrogen $\left(\mathrm{NO}_{\mathrm{X}}\right)$ and oxygen $\left(\mathrm{O}_{2}\right)$ will also be removed, but to be conservative, the flow sheet assumes there will be no removal of these components. The scrubber off-gas then goes to the plant filter plenum. The scrubber bottoms stream joins the condenser condensate in storage and the bottoms are then evaporated in a waste evaporator. The evaporator distillate is sampled and, if the $\mathrm{Pu}$ concentration is low enough, joins the feed evaporator distillate and is sent to waste treatment. The evaporator bottoms stream, assumed to contain some very small level of $\mathrm{PuO}_{2}$, is sent to contaminated waste disposal.

\section{Advantages and Disadvantages}

The following advantages and disadvantages of the fluid bed process were compiled from literature research and from conversations with individuals having operating experience with the process. A separate report will be published at a later date which will compare various denitration processes as to the advantages and disadvantages as they exist in present techinology.

\section{Advantages}

1. Excellent mass transfer between solid and gas.

2. Excellent heat transfer and ease of temperature control.

3. High mobility of solids, permitting simplicity of handling.

4. Simplicity of equipment design with an absence of moving parts.

5. A large capacity per unit volume of equipment.

6. Easily adapted to remote operation.

7. Minimum maintenance requirements.

8. The process should not be hazardous to operate because no dangerous materials are involved other than the plutonium being processed.

9. The process does not require any feed preparation other than an evaporation step.

10. No significant recycle streams are involved in the fluid bed process.

11. Compared with most other processes, fewer inventory problems exist. An excessive amount of plutonium will not be in the production stream at any one time.

\section{Disadvantages}

1. The fluid bed process produces large volumes of waste gases that have to be treated.

2. The process has limited experience with plutonium and has no remote operating experience. Therefore, it will require extensive development to determine the operating parameters.

3. The fluid bed process does not purify the product. A feed solution of sufficient purity will be needed to obtain an oxide that will meet sperifications. 
4. The process is relatively energy intensive. Possibly, a significant amount of power would be needed for proper operation.

\section{Research and Development}

As defined from the results of a literature search and from discussions with those who have experience with fluid bed denitrators, the following development work should be completed prior to the building of a production facility:

1. A glass prototype should be used to develop information concerning the behavior of a $\mathrm{PuO}_{3}$ bed. The ability to see bed action under various conditions of fluidizing air velocity and jet grinder velocity should provide considerable insight in developing a metal operating denitrator.

2. More research should be done on the selection of the optimum bed temperature. Literature has indicated that particle size and other characteristics of the oxide will vary with the temperature, but too little research has been done to insure a workable production unit.

3. The proper nozzle design and location are apparently critical factors for the successful operation of the fluid bed. Nozzles tend to erode with time, and become loose in the shell due to contraction and expansion. Also, there is a problem of nozzle-caking which had been a major problem in the production of $\mathrm{UO}_{3}$ in a fluid bed. The location of the nozzle with respect to the bed also seems to he important Especially important is the development of a nozzle which can easily be changed remotely.

4. Although some development work has been done on the jet grinder, ${ }^{11}$ more should be done to determine the optimum operating conditions. The optimum length of the tube inside the denitrator must be determined, as well as the optimum air flow for particle size control. Also, a control system should be developed which automatically determines particle size distribution and reports it for either automatic adjustment of particle size reduction or manual adjustment from a remote control board. It could be determined from the development work that the jet grinder may not be needed.

5. Most of the uranyl nitrate fluid bed units have exhibited the problem of clogging of the overflow tube and other various parts in addition to the nozzle. The solutions to this problem have traditionally been to vibrate the various parts or to tap with a hammer. It may be that some vibratory feature will have to be designed into the unit.

6. Relatively long runs should be made to determine the problems that would be encountered in a production unit. Also, long runs would provide. a better understanding of the destgn pioblems in remoting.

7. Some research should be done to determine what the effects of certain process parameters, such as residual nitrate, will have on product quality.

\section{CONCLUSIONS}

The fluid bed direct-denitration process appears feasible for reprocessing Light Watcr Reactor fuel. It offers numerous advantages, mainly that of simplicity, over other processes; however, several disadvantages, such as the production of large volumes of waste gases, a lack of purification capability, a relatively large energy requirement, and the fact that it has little experience with $\mathrm{Pu}$, exist in the process. Further development work will be required before the process can be used in a production facility.

\section{REFERENCES}

1. "The Generic Environmental Statement on the Use of Recycle Plutonium in Mixed Oxide Fuel in LWR's." Atomic Energy Commission. Directorate of Licensing, Volumes 1, 2, 3, and 4. Washington, D.C. August 1974.

2. A. A. Jonke, E. J. Petkus, J. W. Loeding, and S. Lawroski. "The Use of Fluidized Beds for the Continuous Drying and Calcination 
of Dissolved Nitrate Solids." Nuclear Science and Engineering. 303:319. 1957.

3. E. Hawthorn, L. P. Shorts, and J. E. Lloyd. "The. Fluidized Solids Dryway Process for the Production of Uranium Tetrafluoride at Springfields." Transactions of the Institution of Chemical Engineers, Volume 38. 197:215. 1960.

4. S. Simecek and W. T. Trask: The Integrated Fluid-Bed System. MCW-1478. Mallinckrodt Chemical Works Uranium Division. Weldon Spring, Missouri. June 10, 1963.

5. S. N. Robinson and J. E. Todd. Plant-Scale Fluid-Bed Denitrator. MCW-1509. Mallinckrodt Chemical Works Uranium Division. Weldon Spring, Missouri. August 1, 1966.

6. W. J. Bjorklund and G. F. Offutt. First Product Denitration Campaign with Enriched Uranium at ICPP. IN-1475. Idaho Nuclear Corporation. Idaho Falls, Idaho. June 1971.

7. W. J. Bjorklund and G. F. Offutt. Testing of the ICPP Fluidized Bed Denitration Process Plant and Pilot-Plant Operation and Associated Chemical Development. ACI-103. Allied Chemical Corporation; Idaho Chemical Programs. Idaho Falls, Idaho. October 1971.

8. P. G. Alfredson, Ptlot Plant Development of Processes for the Production of Nuclear Grade Uranium Oxide. AAEC/E-245. Australian Atomic Energy Commission Research Establishment. Lucas Heights. November 1972.

9. D. S. Webster, A. A. Jonke, W. E. Miller, N. M. Levitz, R. C. Vogel, and M. J. Steindler. Chemical Engineering Division, Fuel Cycle Technology Quarterly Report. ANL 7972. Argonne National Laboratory, Illinois. July-September 1972.
10. D. S. Webster, A. A. Jonke, N. M. Levitz, W. E. Miller, M. J. Steindler, R. C. Vogel, and L. Burris. Chemical Engineering Division, Fuel Cycle Technology Final Report. ANL-7994. Argonne National Laboratory, Illinois. March 1973.

11. G. W. Hogg. Particle Size Control by Jet Grinding in a Fluidized Bed Denitrator. IN-1439. Idaho Nuclear Corporation, Idaho Falls, Idaho. November 1970.

\section{RESEARCH REFERENCES}

Additional information, pertinent to the fluid bed direct-denitraton process can be found in the following:

1. A. G. Fane, B. G. Charlton, and P. G. Alfredson. Thermal Denitration of Uranyl Nitrate in a Fluidized Bed Reactor. AAEC/E-284. Australian Atomic Energy Commission Research Establishment. Lucas Heights. July 1974.

2. S. Vogler, D. E. Grosvenor, N. M. Levitz, and F. G. Teats. Development Studies on a Fluidized Bed Process for Conversion of U/Pu Nitrates to Oxides; Part I - Laboratory Scale Denitration Studies. ANL-7917. Argonne National Laboratory, Illinois. April 1972.

3. D. S. Webster, A. A. Jonke, G. J. Bernstein, N. M. Levitz, R. D. Pierce, M. J. Steindler, and. R. C. Vogel. Chemical Engineering Division, Fuel Cycle Technology Quarterly Report. ANL-7755. Argonne National Laboratory, Illirivis. July, August, September 1970.

4. D. S. Webster, A. A. Jonke, G. J. Bernstein, N. M. Levitz, W. E. Miller, M. J. Steindler, and R. C. Vogel. Chemical Engineering Division, Fuel Cycle Technology Quarterly 
Report. ANL-7946. Argonne National Laboratory, Illinois. April-June 1972.

5. W. J. Bjorklund and G. F. Offutt. "Fluidized Bed Denitration of Uranyl Nitrate." $A I C h E$ Symposium Series. 123:129. 1973.

6. N. M. Levitz, D. E. Grosvenor, S. Vogler, F. G. Teats, and N. Quattropani. "Continuous Conversion of Uranium/Plutonium Nitrates to Oxides." Nuclear Technology. Volume 20. 60:63. October 1973.

7. B. F. Campbell. Comparative Evaluation of the Agitated Through and Fluidized Bed Denitration Process for Application to the Hanford NPE Program. HW-61594. Hanford
Atomic Products Operation. Richland, Washington. June 1, 1959.

8. J. M. Gerhart. A Proposed Fluidized Bed Denitration Unit for use with Enriched Uranium. HW-54805. Hanford Atomic Products Operation. Richland, Washington. 1958.

9. R. W. McKee, A Survey of the Application for the Fluidized Bed UNH Denitration Process at Hanford. HW-47639. Hanford Atomic Products Operation. Richland, Washington. December 28, 1956.

10. G. F. Offutt. Safety Analvsis Repnrt for the ICPP Denitration Process. IN-1293. Idaho Nuclear Corporation. Idaho Falls, Idaho. January 1970.

I L L U S T R A T I O N S

Figures 1 through 3 
DIRECT DENITRATION (FLUID BED)

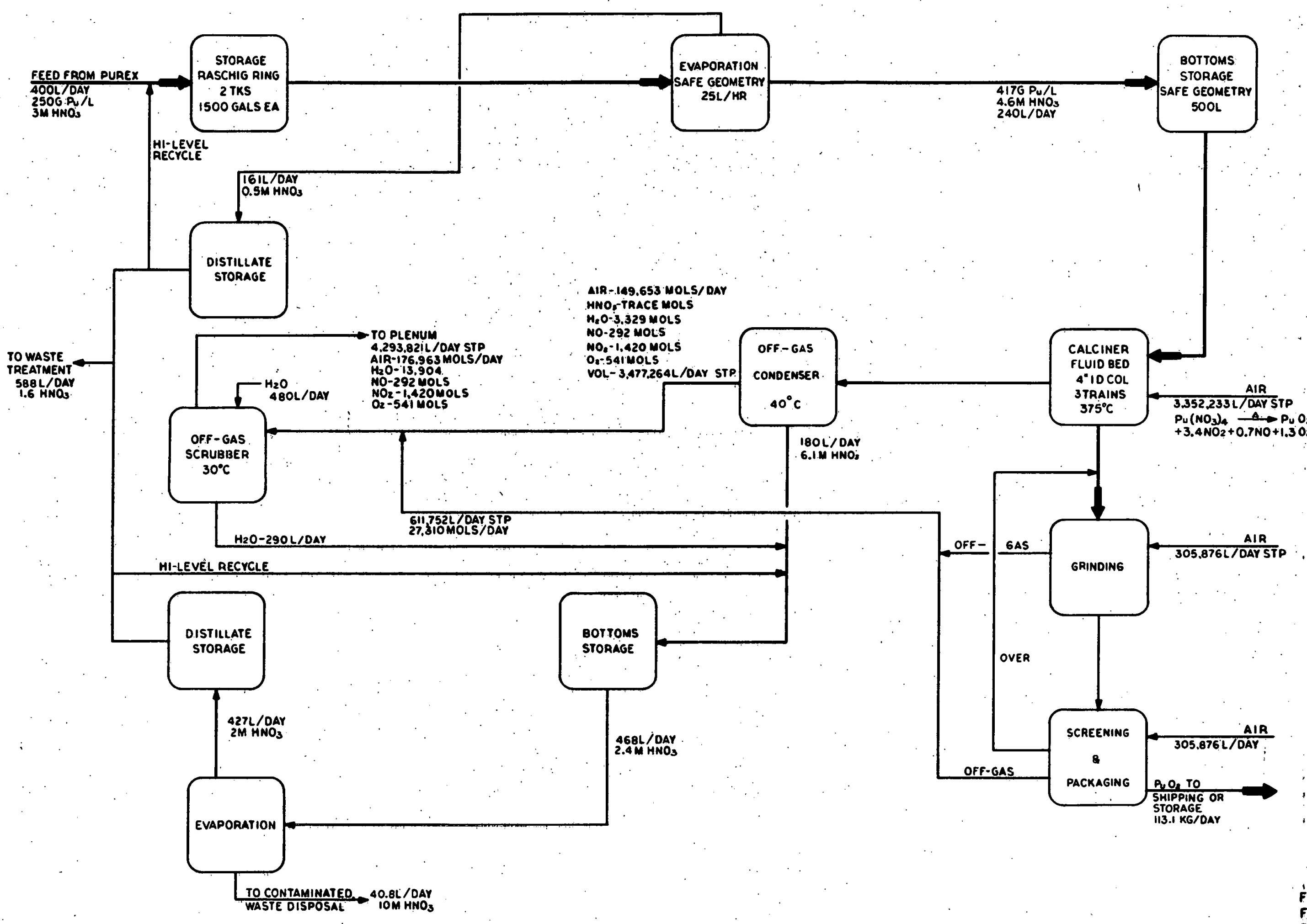




\section{LEGEND SHEET FOR "PNO" FLOW SHEETS}

EQUIP. SYMBOL

$\longrightarrow$

$-\rightarrow 0$

$\rightarrow$ की

叶
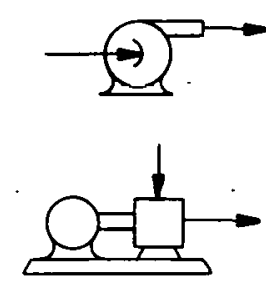

$\square$
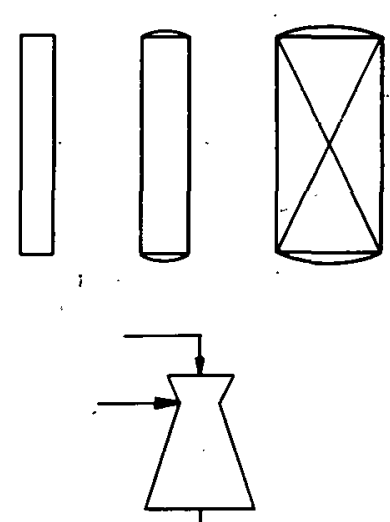

MISCELLANEOUS

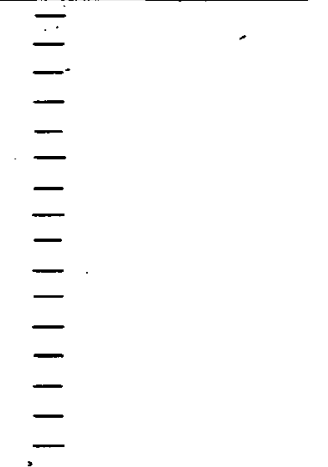

LETTER SYMBOL

$\mathbf{P}$

$\mathbf{P}$

$\mathbf{P}$

C

E

$D, R$

$\checkmark$

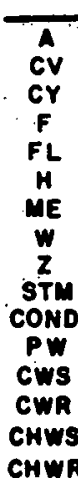

DESCRIPTION

LINE IDENTIFICATION

CENTRIFUAL PUMP

GEAR: PUMP

DIAPHRAGM PUMP

BLOWER

COMPRESSOR

HEAT EXCHANGER

VESSEL , REACTOR

JET, EDUCTOR

AGITATOR

CONVEYO
CYELONE

FURANCE

FILTER
HOPPER

MISCELLANCO
MPYER
ViBRATOR

SIBRATOR

CONDENSATE
PROCESS WATER

COOLNN WATER SUPPLY

CHILLED MATER SUPPLY

CHILLED WATER RETURN
FIGURE 2.

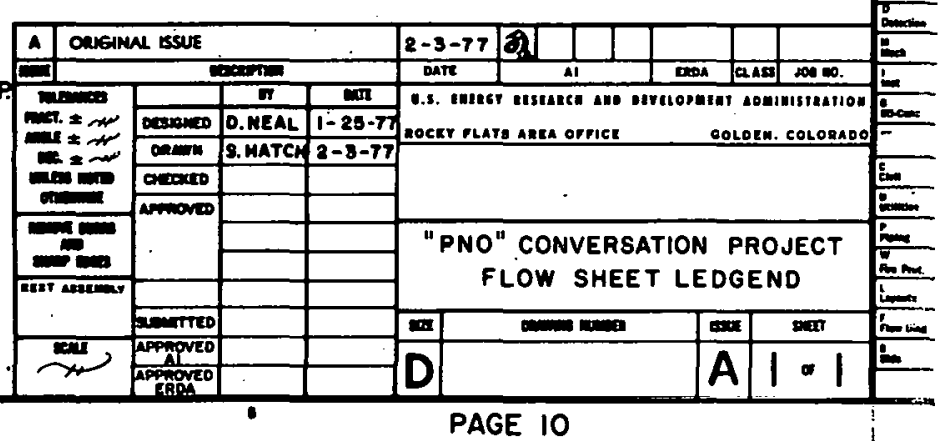




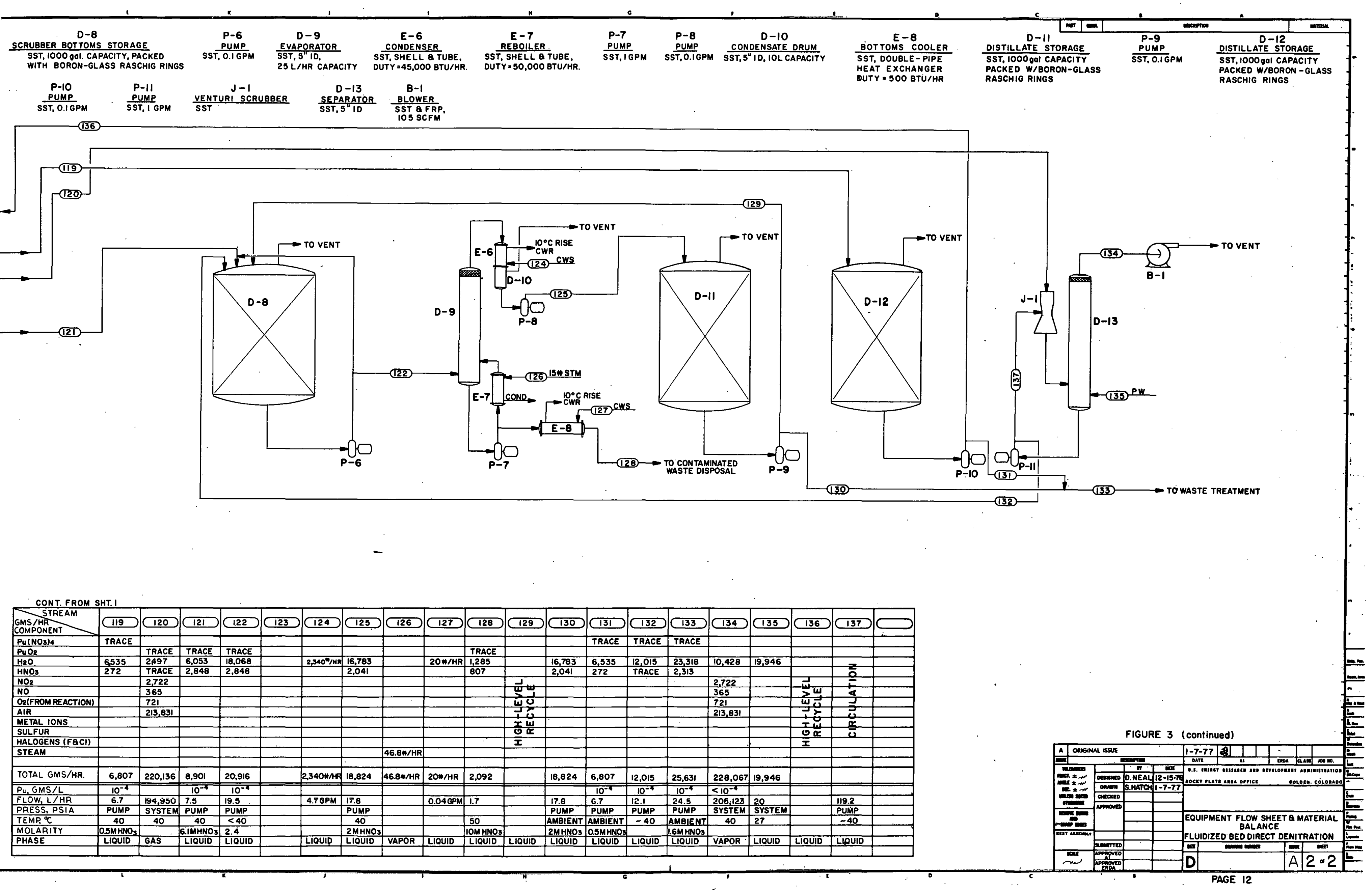

